\title{
Influence of Organic Acids on Nutrients Availability from Natural Alternative Fertilizers
}

\author{
Wafaa M. A. Seddik, Wagida Z. Hassan and Hanaa A. \\ Zein El-Abdeen \\ Soil, Water and Environ. Res. Inst., Agric. Res. Center, Giza, Egypt.
}

\begin{abstract}
A FIELD experiment was carried out during the summer A season with sesame and the winter season with wheat crops in a sandy soil at the Ismailia Agric. Res. Station. The work aimed to study the role of organic acids in nutrients availability and productivity of both indicated crops. Urea- formaldehyde, rock phosphate, feldspar and acidulation with different organic acids ((humic, fulvic, tartaric, salicylic and oxalic) and mineral acid sulphuric) at two concentrations 10 and $15 \%$ (C1) and (C2) were used. Results revealed that acidulation had positive effect on chemical properties as well as availability of soil N, P and K nutrients compared to the control treatments; soil $\mathrm{pH}$ decreased especially with $\mathrm{C} 2$ which relatively raised soil EC. Also, there was a significant increase in the availability of $\mathrm{N}, \mathrm{P}$ and $\mathrm{K}$ in soil; again, the superiority was with the second concentration. There was a significant response to acidulation compared to the control treatment when assessing yield of each grains or seeds and straw of both wheat and sesame crops, especially when using the second concentration (C2). An increase in the total content of NPK elements with acidulation treatments compared to the control for both wheat and sesame crops was observed. The results also showed high response to salicylic acid compared to other acids while the oxalic acid being inferior. Finally, urea- form, rock phosphate and feldspar (alternative fertilizer) under acidulation with different acids could be a promising approach to enhance release of available $\mathrm{N}, \mathrm{P}$ and $\mathrm{K}$ and to improve soil chemical properties which will be reflected on the yield along with total content of nutrients.
\end{abstract}

Keywords: Acidulation, Urea-form, Rock phosphate, Feldspar, Macronutrients availability, Wheat and sesame yield

It is worth mentioning that fertilization became expensive; therefore it is necessary to consider the use of some natural rocks such as feldspar, rock phosphate especially with acid treatment for easing the release of elements contained in these materials.

Mineral fertilizers, particularly those of mineral-N, are important for plant nutrition (Hartman, 1988). The efficiency of $\mathrm{N}$ fertilizer can be increased through the use of slow release $\mathrm{N}$ forms, which potentially reduce nitrogen leaching losses, particularly in sandy soils extending $\mathrm{N}$ availability over the growing season and improving the efficiency of 
plant recovery (Wang and Alva, 1996). Also, Hassan et al. (2010) showed that ureaformaldehyde (UF) treatments, either as full or half dose, had positive effects on vegetative growth of plants. The authors added that UF treatments increased the available forms of $\mathrm{N}, \mathrm{P}$ and $\mathrm{K}$ in the sandy soil for the four grown crops seedling in comparison with the traditional urea. Furthermore, Seddik et al. (2011) reported that application of UF as slow release fertilizer at a rate of $(75 \% \mathrm{~N})$ in presence of compost improved chemical properties and increased yield components of carrot as well as its total content of macronutrients and is economically feasible.

Phosphorus is a key nutrient element for the growth and development of crops (Wang et al., 2011). Phosphorus is provided mainly by soil, however, it can easily be immobilized in soil, and the seasonal application rate of phosphate fertilizer for crops is only 10-25\% (Liu et al., 2012).

Application of rock phosphates in arid and semi-arid regions is not common, because of its low availability giving the fact that most soils are alkaline under drought stress, relatively high in $\mathrm{pH}$, and low in organic matter. A number of studies have examined the solution of rock phosphate (RP) in soils and its subsequent effect on soil reactivity such as soil $\mathrm{pH}$, particle size of the $\mathrm{RP}$, along with concentrations of $\mathrm{Ca}$ and $\mathrm{P}$ in the soil solution (He et al., 2005). On the other hand, calcareous soils are frequently characterized by its low bioavailability of plant nutrients due to high base status with $\mathrm{pH}$ variable between 7.5 - 8.5 and the presence of carbonate minerals (Marschner, 1995). The efficiency of $\mathrm{P}$ fertilizers in these soils is generally very low because $\mathrm{P}$ applied to the soil reacts with $\mathrm{Ca}$ forming minerals such as dicalcium phosphate dehydrate and tricalcium phosphate.

Concerning $\mathrm{K}$, its main source for plants growing under natural conditions comes from the weathering of $\mathrm{K}$ minerals and organic $\mathrm{K}$ - sources such as compost and plant residues. Potassium from feldspar mineral could be solubilized and transformed into available form when incorporated with organic materials such as compost or vinasse (Seddik, 2011).

The increases in $\mathrm{K}$ uptake reduce the concentration of $\mathrm{K}$ in the soil solution and root surfaces thus induce the release of $\mathrm{K}$ held on the external surfaces of soil particles and also the gradual release of $\mathrm{K}$ from the interlayer.Therefore, the use of natural minerals, especially feldspar and compost combined with organic residues should be considered as natural alternatives and beneficial cheap sources of $\mathrm{K}$ fertilization for sustainable agriculture in sandy soils (Singh et al., 2002).

In many studies, humic and fulvic acids preparations were reported to increase the uptake of mineral elements to promote the root length (Canellas et al., 2002) and to increase the fresh and dry weights of crop plants (Chen et al., 2004 a, b). Due to the positive effect of humic substances on the visible growth of plants, these chemicals have been widely used by the growers instead of other substances. This, however, has led to growers using higher amounts of commercial substances.

Humic acid is considered a suitable application for improving the vegetative growth, yield production and the antioxidant activity of the plants (Yasser et al., 2011). Humic Egypt. J. Soil Sci. 56, No.3 (2016) 
acids may improve urea $\mathrm{N}$ use efficiency as well as reducing environmental pollution by increasing soil exchangeable $\mathrm{NH}_{4}{ }^{+}$and available $\mathrm{NO}_{3}{ }^{-}$while retaining more $\mathrm{N}$ in the soil (Yusuff et al., 2009). Also, humic substances can improve water holding capacity for better drought resistance and reduction in water usage (Russo and Berlyn, 1990). In addition, soil structure is influenced by humic and fulvic acids participating in numerous bridging mechanisms, including water, $\mathrm{Al}$, and $\mathrm{Ca}$ bridging (Tan, 2003). Stimulation of root growth is generally more apparent than stimulation of shoot growth (Nardi et al., 1996).

Moreover, humic acid applications can improve the stability of soil structure. Physical and chemical properties of soil such as soil organic carbon, total nitrogen, modulus of rupture and aggregate stability were improved by HA amendment. According to reported results, HA (K-Humate) has potential to be used as an effective management tool for sustainability of the soil environment (Gümü and Seker, 2015)

It is worth mentioning that, citric acid, tartaric acid and oxalic acid of different concentrations application into soil, increase the content of available P. When the concentration of acids were reduced to $1 \mathrm{mmol} / \mathrm{L}$, both the total and maximum release amount of soil P significantly declined, the order being citric acid $<$ malic acid $<$ oxalic acid and acetic acid (Lv et al., 2015). Also, the outhouse added that, the parabolic diffusion equation showed that organic acids can improve the migration rate of phosphorus in the soil. Salicylic acid (SA) application has been reported to enhance plant tolerance to many abiotic stress SA alters some plants physiological functions. These functions may work as a key role in enhancing plants tolerance to salt stress (Srivastava and Dwivedi, 2000).

Therefore, the objective of this study is to evaluate efficiency of using natural sources (urea formaldehyde, rock phosphate and feldspar) as alternative fertilizers through acidulation with organic acids on availability of macronutrient and yield productivity of sesame and wheat.

\section{Materials and Methods}

A field experiment was carried out at Ismailia Agric. Res. Station, ARC during the summer season with sesame (Sesamumindicum L. var., Giza 32) and the winter sprinkler irrigation system to evaluate the effectiveness of organic acids (tartaric, salicylic, oxalic, humic and fulvic) and (sulphuric acid) application on $\mathrm{N}, \mathrm{P}$ and $\mathrm{K}$ release from urea formaldehyde, rock phosphate and feldspar. Soil chemical properties and nutrient availability as well as nutritional status of sesame and wheat crops were also evaluated. The institute farm is located at $30^{\circ} 35^{\circ} 41.9^{\prime \prime} \mathrm{N}$ Latitude and $32^{\circ} 16^{\prime} 45.8^{\prime \prime} \mathrm{E}$ longitude. The soil under study was analyzed according to methods described by Cottenie $e t$ al. (1982) as shown in Table 1. Relative chemical properties of organic acids are described in Tables 2 and 3. The experiment was designed in a randomized complete block design with three field replications. 
The control (1) treatment received mineral fertilizers $\left(15 \% \mathrm{P}_{2} \mathrm{O}_{5}\right)$ at a rate of $200 \mathrm{Kg}$ fed. ${ }^{-1}$ basically before sowing; potassium was added in the form potassium sulfate (48\% $\left.\mathrm{K}_{2} \mathrm{O}\right)$ at $50 \mathrm{Kg}$ fed. $^{-1}$, nitrogen was added in the form ammonium sulfate $(20 \% \mathrm{~N})$ rates of 450 and $100 \mathrm{Kg}_{\text {fed. }}{ }^{-1}$ as recommended for wheat and sesame production. The control (2) treatments received nitrogen fertilizer as urea- form $(46 \% \mathrm{~N})$ at rate of 200 and 100 $\mathrm{Kg} \mathrm{fed}^{-1}$ as slow release nitrogen fertilizer, phosphorus as rock phosphate $\left(15 \% \mathrm{P}_{2} \mathrm{O}_{5}\right)$ at rate of $200 \mathrm{Kg}_{\text {fed. }}{ }^{-1}$ and feldspar $\left(10 \% \mathrm{~K}_{2} \mathrm{O}\right)$ at rate of $480 \mathrm{Kg} \mathrm{fed}^{-1}$. Then it was mixed with soil surface two weeks before sesame and wheat cultivation. Soil surface acidulation was performed using either $10(\mathrm{C} 1)$ or $15 \%(\mathrm{C} 2)$ concentrations of the studied acids. Solution volume used in acidulation was $400 \mathrm{~L} /$ feddan (before sesame and wheat cultivation and then added two doses within season). At maturity, sesame and wheat were harvested after 120 day to evaluate yield components (seeds or grains and straw) and nutrient status. Plant samples were oven dried at $70{ }^{\circ} \mathrm{C}$ until constant dry weight, then ground and digested using $\mathrm{H}_{2} \mathrm{SO}_{4}$ and $\mathrm{H}_{2} \mathrm{O}_{2}$ mixture described by Page et al. (1982). Soil chemical properties of soil along with analyses for natural minerals were evaluated according to Cottenie et al. (1982). Obtained results were subjected to statistical analysis according to Snedecor and Cochran (1982), and the treatments were compared by using the least significant difference (L.S.D) at 0.05 level of probability.

\section{TABLE 1. Physical and chemical properties of the experimental soil}

\begin{tabular}{|c|c|}
\hline Soil characteristics & Value \\
\hline $\begin{array}{l}\text { Particle size distribution \% } \\
\text { Coarse Sand } \\
\text { Fine Sand } \\
\text { Silt } \\
\text { Clay } \\
\text { Texture class }\end{array}$ & $\begin{array}{r}50.4 \\
40.4 \\
3.20 \\
6.00 \\
\text { Sandy }\end{array}$ \\
\hline $\begin{array}{l}\text { Chemical properties } \\
\mathrm{CaCO}_{3} \% \\
\mathrm{pH}(\text { Suspension } 1: 2.5 \text { ) } \\
\text { EC dS/m (saturated past extract) } \\
\text { Organic matter \% }\end{array}$ & $\begin{array}{l}1.40 \\
7.92 \\
0.37 \\
0.40\end{array}$ \\
\hline \multicolumn{2}{|c|}{ Soluble cations and anions (meq $\left.\mathrm{L}^{-1}\right)$} \\
\hline $\begin{array}{l}\mathrm{Ca}^{++} \\
\mathrm{Mg}^{++} \\
\mathrm{Na}^{+} \\
\mathrm{K}^{+} \\
\mathrm{CO}_{3}{ }^{--} \\
\mathrm{HCO}_{3-} \\
\mathrm{Cl}^{-} \\
\mathrm{SO}_{4}^{--}\end{array}$ & $\begin{array}{c}0.95 \\
0.89 \\
1.51 \\
0.45 \\
- \\
1.42 \\
1.02 \\
1.36\end{array}$ \\
\hline \multicolumn{2}{|l|}{ Available nutrients $\left(\mathrm{mg} \mathrm{kg}^{-1}\right)$} \\
\hline $\begin{array}{l}\mathrm{N} \\
\mathrm{P} \\
\mathrm{K}\end{array}$ & $\begin{array}{l}66.0 \\
12.0 \\
45.6\end{array}$ \\
\hline
\end{tabular}

Egypt. J. Soil Sci. 56, No.3 (2016) 
INFLUENCE OF ORGANIC ACIDS ON NUTRIENTS AVAILABILITY... 507

TABLE 2. Chemical properties of applied humic and fulvic acids

\begin{tabular}{|c|c|c|}
\hline Characteristics & Humic acid & Fulvic acid \\
\hline pH & 5.56 & 1.23 \\
\hline $\mathrm{EC}\left(\mathrm{dSm}^{-1}\right)$ & 6.52 & 4.61 \\
\hline O.C \% & 9.50 & 4.20 \\
\hline \multicolumn{3}{|c|}{ Total macronutrients \% } \\
\hline $\mathbf{N}$ & 1.29 & 0.42 \\
\hline $\mathbf{P}$ & 0.25 & 0.15 \\
\hline $\mathbf{K}$ & 2.00 & 2.00 \\
\hline
\end{tabular}

TABLE 3. pH and EC of applied acids for soil

\begin{tabular}{|c|c|c|c|}
\hline Treatments & Conc. & pH & EC \\
\hline \multirow{2}{*}{ Humic acid } & $\mathrm{C} 1$ & 1.90 & 2.80 \\
\hline & $\mathrm{C} 2$ & 1.83 & 3.45 \\
\hline \multirow{2}{*}{ Fluvic acid } & $\mathrm{C} 1$ & 2.00 & 1.60 \\
\hline & $\mathrm{C} 2$ & 1.80 & 2.80 \\
\hline \multirow{2}{*}{ Tartaric acid } & $\mathrm{C} 1$ & 1.84 & 10.4 \\
\hline & $\mathrm{C} 2$ & 1.58 & 10.3 \\
\hline \multirow{2}{*}{ Salicylic acid } & $\mathrm{C} 1$ & 1.84 & 11.8 \\
\hline & $\mathrm{C} 2$ & 2.09 & 19.5 \\
\hline \multirow{2}{*}{ Oxalic acid } & $\mathrm{C} 1$ & 1.80 & 78.5 \\
\hline & $\mathrm{C} 2$ & 1.82 & 98.2 \\
\hline \multirow{2}{*}{ Sulphuric acid } & $\mathrm{C} 1$ & 1.20 & 18.2 \\
\hline & C2 & 1.81 & 30.0 \\
\hline
\end{tabular}

Egypt. J. Soil Sci. 56, No.3 (2016) 


\section{Results and Discussions}

\section{Effect of acidulation with different acids on soil characteristics}

Soil pH

Results in Table 4 revealed that application of acidulated to soil treated with urea- form, rock - phosphate and feldspar, decreased soil $\mathrm{pH}$ values compared with the control treatments without organic acids. Favorable effects were more encountered with the $\mathrm{C} 2(15 \%)$ of all organic or mineral acids; this trend was true for both seasons although the $\mathrm{pH}$ values in the second season (wheat crop) increased than the first season probably due to different seasons and related moisture and temperature. The effect of acidity resulting from applied acids were explained by Welch et al. (2002) who found that organic acids contribute to the lowering of solution $\mathrm{pH}$ as they dissociate in a $\mathrm{pH}$ dependent equilibrium, into their respective anion(s) and proton(s). Organic acids buffer solution $\mathrm{pH}$ and should continue to dissociate as protons are consumed by the dissolution reaction. Similarly, microorganisms often export organic acids as anions (Netik et al., 1997).

\section{Electric conductivity (EC)}

Data in Table 4 indicated that, application of acidulated urea- form, rock phosphate and feldspar caused increases in the EC values as compared to the control treatments, in both seasons. The observed increase in soil EC might be due to the indirect effect of lowering soil $\mathrm{pH}$, which consequently leads to dissolving nutrients in the soil solution and thus resulting in higher EC. This is similar with the data of Seddik and Osman (2015) who found that, humic and fulvic acids contain more nutrients, different elements and function groups with high molecular weight and carbon contents. Also, organic acids play an important role in improving bioavailability of soil nutrients which cause an increase in the EC of the soil along with mineral acids generally increased EC values as compared to control treatment. This may be due to the presence of hydrogen ion which lowered the soil $\mathrm{pH}$ reflected on increasing the rate dissolution of feldspar and increasing the electric conductivity due to improving nutrients availability.

\section{Soil available N, $P$ and $K$}

Data in Table 5 show an increase in available $\mathrm{N}, \mathrm{P}$ and $\mathrm{K}$, at both seasons, under treatments (urea form, rock phosphate and feldspar) as a result of acidification with organic or mineral acids compared to the control treatments (without acidification). This may be due to the effect of organic acid on mineral weathering rates through at least three mechanisms: changing the dissolution 
INFLUENCE OF ORGANIC ACIDS ON NUTRIENTS AVAILABILITY... 509

rate through decreasing solution $\mathrm{pH}$ or forming complexes with cations at the mineral surface; and affecting the saturation state of the solution with respect to mineral and affecting the speciation in solution of ions (Song and Huang, 1988).

TABLE 4. Effect of natural alternative fertilizes acidulation on $\mathrm{pH}$ and $\mathrm{EC}$ values of soil for sesame and wheat at two seasons

\begin{tabular}{|c|c|c|c|c|c|}
\hline \multirow{2}{*}{ Treatments } & \multirow{4}{*}{ Conc. } & Sesame & Wheat & Sesame & Wheat \\
\hline & & \multicolumn{2}{|c|}{ pH (suspension 1:2.5) } & \multicolumn{2}{|c|}{$\mathrm{EC} \mathrm{dSm} \mathbf{S O}^{-1}$} \\
\hline $\operatorname{con} 1$ & & 7.62 & 7.80 & 0.57 & 0.52 \\
\hline $\operatorname{con} 2$ & & $7.75 \mathrm{a}$ & $7.90 \mathrm{a}$ & $0.61 \mathrm{f}$ & $0.50 \mathrm{~g}$ \\
\hline \multirow{3}{*}{ Humic } & $\mathrm{C} 1$ & 7.43 & $7.64 \mathrm{~b} \mathrm{c} \mathrm{d}$ & $0.95 \mathrm{bc}$ & $0.81 \mathrm{~d}$ \\
\hline & $\mathrm{C} 2$ & $7.31 \mathrm{~d}$ & $7.52 \mathrm{~cd}$ & $1.10 \mathrm{a}$ & $1.01 \mathrm{a}$ \\
\hline & Mean & $7.37 \mathrm{~d}$ & $7.58 \mathrm{~cd}$ & $1.02 \mathrm{a}$ & $0.91 \mathrm{a}$ \\
\hline \multirow{3}{*}{ Fulvic } & $\mathrm{C} 1$ & $7.48 \mathrm{bc} \mathrm{d}$ & $7.60 \mathrm{~cd}$ & $0.82 \mathrm{c} \mathrm{de}$ & $0.78 \mathrm{de}$ \\
\hline & $\mathrm{C} 2$ & $7.36 \mathrm{~cd}$ & $7.47 \mathrm{~d}$ & $1.00 \mathrm{a}$ & $0.93 \mathrm{abc}$ \\
\hline & Mean & $7.42 \mathrm{~cd}$ & $7.54 \mathrm{de}$ & $0.91 \mathrm{~b}$ & $0.85 \mathrm{~b}$ \\
\hline \multirow{3}{*}{ Tartaric } & $\mathrm{C} 1$ & $7.63 \mathrm{ab}$ & $7.71 \mathrm{abc}$ & 0.73 ef & $0.65 \mathrm{f}$ \\
\hline & $\mathrm{C} 2$ & $7.50 \mathrm{bcd}$ & $7.62 \mathrm{bcd}$ & $1.00 \mathrm{ab}$ & $0.94 \mathrm{ab}$ \\
\hline & Mean & $7.56 \mathrm{~b}$ & $7.66 \mathrm{bc}$ & $0.86 \mathrm{~b}$ & $0.79 \mathrm{c}$ \\
\hline \multirow{3}{*}{ Salicylic } & $\mathrm{C} 1$ & $7.51 \mathrm{bcd}$ & $7.66 \mathrm{bcd}$ & $0.87 \mathrm{~b} \mathrm{c} \mathrm{d}$ & $0.85 \mathrm{c} \mathrm{d}$ \\
\hline & $\mathrm{C} 2$ & $7.40 \mathrm{bc} \mathrm{d}$ & $7.52 \mathrm{e}$ & $0.94 \mathrm{bc}$ & $1.00 \mathrm{a}$ \\
\hline & Mean & $7.45 \mathrm{~b} \mathrm{c} \mathrm{d}$ & 7.59 ef & $0.91 \mathrm{~b}$ & $0.92 \mathrm{a}$ \\
\hline \multirow{3}{*}{ Oxalic } & $\mathrm{C} 1$ & $7.60 \mathrm{abc}$ & $7.80 \mathrm{ab}$ & $0.83 \mathrm{c} \mathrm{de}$ & 0.70 ef \\
\hline & $\mathrm{C} 2$ & $7.51 \mathrm{bcd}$ & $7.71 \mathrm{bc}$ & $0.98 \mathrm{ab}$ & $0.86 \mathrm{bc} \mathrm{d}$ \\
\hline & Mean & $7.56 \mathrm{bc}$ & $7.76 \mathrm{~b}$ & $0.91 \mathrm{~b}$ & $0.78 \mathrm{c}$ \\
\hline \multirow{3}{*}{ Sulphuric } & $\mathrm{C} 1$ & $7.36 \mathrm{~cd}$ & $7.52 \mathrm{e}$ & $0.71 \mathrm{ef}$ & $0.66 \mathrm{e}$ \\
\hline & $\mathrm{C} 2$ & $7.33 \mathrm{~d}$ & $7.48 \mathrm{~d}$ & $0.80 \mathrm{de}$ & $0.72 \mathrm{ef}$ \\
\hline & Mean & $7.34 \mathrm{~d}$ & $7.50 \mathrm{e}$ & $0.75 \mathrm{c}$ & $0.69 \mathrm{~d}$ \\
\hline
\end{tabular}

Control $1=$ fertilizer as recommended dose

Control 2= Urea -form + rock $-\mathrm{P}+\mathrm{K}$-feldspar 
TABLE 5. Effect of natural alternative fertilizers acidulation on availability of macronutrients in sandy soil

\begin{tabular}{|c|c|c|c|c|c|c|c|}
\hline \multirow{3}{*}{ Treatments } & \multirow{3}{*}{ Conc. } & \multicolumn{3}{|c|}{ Sesame season } & \multicolumn{3}{|c|}{ Wheat season } \\
\hline & & \multicolumn{3}{|c|}{ Available (mg Kg $\left.{ }^{-1}\right)$} & \multicolumn{3}{|c|}{ Available (mg Kg $\left.{ }^{-1}\right)$} \\
\hline & & $\mathbf{N}$ & $\mathbf{P}$ & $\mathbf{K}$ & $\mathbf{N}$ & $\mathbf{P}$ & $\mathbf{K}$ \\
\hline control $1^{*}$ & & 110 & 18 & 50 & 105 & 19 & 62 \\
\hline control 2* & & $108 \mathrm{~g}$ & $17 \mathrm{~g}$ & $44 \mathrm{j}$ & $98 \mathrm{j}$ & $18 \mathrm{e}$ & $56 \mathrm{~g}$ \\
\hline \multirow{3}{*}{ Humic } & $\mathrm{C} 1$ & $155 \mathrm{c}$ & 20 e f & $84 \mathrm{~d}$ & $150 \mathrm{~d} \mathrm{e}$ & $24 \mathrm{c}$ & $90 \mathrm{c} \mathrm{d}$ \\
\hline & $\mathrm{C} 2$ & $164 \mathrm{~b}$ & $22 \mathrm{~cd}$ & $100 \mathrm{a}$ & $163 \mathrm{~b}$ & $33 \mathrm{a}$ & $104 \mathrm{~b}$ \\
\hline & Mean & $160 \mathrm{a}$ & $21 \mathrm{c}$ & $92 \mathrm{a}$ & $157 \mathrm{~b}$ & $29 \mathrm{a}$ & $97 \mathrm{a}$ \\
\hline \multirow{3}{*}{ Fulvic } & $\mathrm{C} 1$ & $140 \mathrm{de}$ & 19 e f & $80 \mathrm{e}$ & 148 e f & $22 \mathrm{~d}$ & $88 \mathrm{c} \mathrm{d} \mathrm{g}$ \\
\hline & $\mathrm{C} 2$ & $152 \mathrm{c}$ & 20 e f & $96 \mathrm{~b}$ & $156 \mathrm{c}$ & $25 \mathrm{c}$ & $94 \mathrm{c}$ \\
\hline & Mean & $146 \mathrm{~b}$ & $19 \mathrm{c}$ & $88 \mathrm{~b}$ & $152 \mathrm{c}$ & $24 \mathrm{~b}$ & $91 \mathrm{~b}$ \\
\hline \multirow{3}{*}{ Tartaric } & $\mathrm{C} 1$ & $120 \mathrm{f}$ & $21 \mathrm{~d} \mathrm{e}$ & $60 \mathrm{~h}$ & $115 \mathrm{i}$ & $21 \mathrm{~d}$ & $73 \mathrm{f}$ \\
\hline & $\mathrm{C} 2$ & $134 \mathrm{e}$ & $28 \mathrm{~b}$ & $75 \mathrm{f}$ & $127 \mathrm{~h}$ & $22 \mathrm{~d}$ & $87 \mathrm{c} \mathrm{de}$ \\
\hline & Mean & $127 \mathrm{~d}$ & $24 \mathrm{~b}$ & $67 \mathrm{~d}$ & $121 \mathrm{e}$ & $21 \mathrm{~b}$ & $80 \mathrm{~d}$ \\
\hline \multirow{3}{*}{ Salicylic } & $\mathrm{C} 1$ & $148 \mathrm{~cd}$ & $23 \mathrm{~cd}$ & $83 \mathrm{~d}$ & $153 \mathrm{c} \mathrm{d}$ & $25 \mathrm{c}$ & $92 \mathrm{c} \mathrm{d}$ \\
\hline & $\mathrm{C} 2$ & $180 \mathrm{a}$ & $30 \mathrm{a}$ & $95 \mathrm{~b}$ & $172 \mathrm{a}$ & $31 \mathrm{~b}$ & $111 \mathrm{a}$ \\
\hline & Mean & $164 \mathrm{a}$ & $27 \mathrm{a}$ & $89 a b$ & $162 \mathrm{a}$ & $28 \mathrm{a}$ & $102 \mathrm{a}$ \\
\hline \multirow{3}{*}{ Oxalic } & $\mathrm{C} 1$ & $125 \mathrm{f}$ & $19 \mathrm{f}$ & $55 \mathrm{i}$ & $140 \mathrm{~g}$ & $22 \mathrm{~d}$ & $82 \mathrm{e}$ \\
\hline & $\mathrm{C} 2$ & $140 \mathrm{de}$ & $22 \mathrm{c}$ & $63 \mathrm{~g}$ & 146 e f & $24 \mathrm{c}$ & $88 \mathrm{~cd} \mathrm{e}$ \\
\hline & Mean & $133 \mathrm{c}$ & $20 \mathrm{c}$ & 59 e & $143 \mathrm{~d}$ & $23 \mathrm{~b}$ & $85 \mathrm{c} \mathrm{d}$ \\
\hline \multirow{3}{*}{ Sulphuric } & $\mathrm{C} 1$ & $141 \mathrm{de}$ & $19 \mathrm{f}$ & $80 \mathrm{e}$ & $137 \mathrm{~d} \mathrm{e}$ & $19 \mathrm{e}$ & $86 \mathrm{~d} \mathrm{e}$ \\
\hline & $\mathrm{C} 2$ & $155 \mathrm{c}$ & $22 \mathrm{~cd}$ & $86 \mathrm{c}$ & $150 \mathrm{fg}$ & $22 \mathrm{~d}$ & $90 \mathrm{c} \mathrm{d}$ \\
\hline & Mean & $148 \mathrm{~b}$ & $21 \mathrm{c}$ & $83 c$ & $144 \mathrm{~d}$ & $21 \mathrm{bc}$ & $88 \mathrm{~b} \mathrm{c}$ \\
\hline
\end{tabular}

Control $1=$ fertilizer as recommended dose

Control 2= Urea - form + rock $-\mathrm{P}+\mathrm{K}$ - feldspar

Obtained results also showed that available nutrients for the two seasons were greater with salicylic and humic acids treatment compared to other organic or mineral acids. Ali et al. (2015) found that, using organic acids such as humic and salicylic acids play important roles in nutrient soluble and attracting beneficial microorganisms. Also, organic acids improve calcium availability which buffers $\mathrm{pH}$ in soil. Oxalic acid treatment was inferior. This was explained by Chen et al. (2000) who found the various organic acids can effectively dissolve minerals and chelate metallic cations, the great effect of organic acid on dissolution of rocks and minerals may be attributed to the presence of hydrogen ions and the formation of cationcomplexes. Similar results were reported by Lv et al. (2015). Finally, values of available N, P and K were superior at high rates of applied acids. Ugolini and Sletten (1991) found that the levels of organic acids were affected by a number of independent variables such as $\mathrm{pH}$ redox potential.

Egypt. J. Soil Sci. 56, No.3 (2016) 
INFLUENCE OF ORGANIC ACIDS ON NUTRIENTS AVAILABILITY.. 511

\section{Effect of acidulation on plant}

Yield components

Data presented in Table 6 indicted that the yield values of seeds and straw for sesame and grains and straw for wheat crops at both studied seasons were generally, increased significantly by treatments with acidulated urea- form, rock- phosphate and feldspar (alternative fertilizer) compared to control treatment, the second rate of acids being superior. As expected, when compared to control with recommended dose of NPK treatments and control with including those of no acidulation of urea- form, rock- phosphate and feldspar the latter was inferior than advanced.

TABLE 6. Effect of natural alternative fertilizer acidulation on yield components of sesame and wheat crops

\begin{tabular}{|c|c|c|c|c|c|}
\hline \multirow{2}{*}{ Treatments } & \multirow{2}{*}{ Conc. } & \multicolumn{2}{|c|}{ Sesame yield $\mathrm{Kg}$ fed $^{-1}$} & \multicolumn{2}{|c|}{ Wheat yield $\mathrm{Kg}$ fed $^{-1}$} \\
\hline & & Seeds & Straw & Grain & Straw \\
\hline control $1 *$ & & 260 & 1600 & 1765 & 2000 \\
\hline control $2^{*}$ & & $252 \mathrm{j}$ & $1550 \mathrm{~g}$ & $1700 \mathrm{j}$ & $1950 \mathrm{i}$ \\
\hline \multirow{3}{*}{ Humic } & $\mathrm{C} 1$ & $300 \mathrm{j}$ & $1600 \mathrm{f}$ & $2600 \mathrm{fg} \mathrm{h}$ & $2610 \mathrm{fg}$ \\
\hline & $\mathrm{C} 2$ & $335 \mathrm{e}$ & $1720 \mathrm{e}$ & $2700 \mathrm{def}$ & $2730 \mathrm{de}$ \\
\hline & Mean & $317 \mathrm{~d}$ & $1660 \mathrm{~d}$ & $2650 \mathrm{~cd}$ & $2670 \mathrm{c} \mathrm{d}$ \\
\hline \multirow{3}{*}{ Fulvic } & $\mathrm{C} 1$ & $320 \mathrm{f}$ & $1700 \mathrm{e}$ & 2665 e f g & $2700 \mathrm{def}$ \\
\hline & $\mathrm{C} 2$ & $370 \mathrm{~d}$ & $1820 \mathrm{~d}$ & $2785 \mathrm{c} \mathrm{de}$ & $2800 \mathrm{~d}$ \\
\hline & Mean & $345 \mathrm{c}$ & $1760 \mathrm{c}$ & $2725 \mathrm{c}$ & $2750 \mathrm{c}$ \\
\hline \multirow{3}{*}{ Tartaric } & $\mathrm{C} 1$ & $372 \mathrm{~d}$ & $1830 \mathrm{~d}$ & $2800 \mathrm{c} \mathrm{d}$ & 2915 c \\
\hline & $\mathrm{C} 2$ & $390 \mathrm{c}$ & $1900 \mathrm{c}$ & $2970 \mathrm{~b}$ & $3000 \mathrm{c}$ \\
\hline & Mean & $381 \mathrm{~b}$ & $1865 \mathrm{~b}$ & $2885 \mathrm{~b}$ & $2958 \mathrm{~b}$ \\
\hline \multirow{3}{*}{ Salicylic } & $\mathrm{C} 1$ & $400 \mathrm{~b}$ & $1950 \mathrm{~b}$ & $2900 \mathrm{~b} \mathrm{c}$ & $3110 \mathrm{~b}$ \\
\hline & $\mathrm{C} 2$ & $460 \mathrm{a}$ & $2100 \mathrm{a}$ & $3210 \mathrm{a}$ & $3300 \mathrm{a}$ \\
\hline & Mean & $430 \mathrm{a}$ & $2025 \mathrm{a}$ & 3055 a & 3205 a \\
\hline \multirow{3}{*}{ Oxalic } & $\mathrm{C} 1$ & $275 \mathrm{i}$ & $1600 \mathrm{f}$ & $2415 \mathrm{i}$ & $2480 \mathrm{~h}$ \\
\hline & $\mathrm{C} 2$ & $290 \mathrm{~h}$ & $1700 \mathrm{e}$ & $2500 \mathrm{~h} \mathrm{i}$ & 2620 e f g \\
\hline & Mean & $282 \mathrm{f}$ & $1650 \mathrm{~d}$ & 2457 e & $2550 \mathrm{e}$ \\
\hline \multirow{3}{*}{ Sulphuric } & $\mathrm{C} 1$ & $290 \mathrm{~h}$ & $1600 \mathrm{f}$ & $2540 \mathrm{~g} \mathrm{~h} \mathrm{i}$ & $2570 \mathrm{~g} \mathrm{~h}$ \\
\hline & $\mathrm{C} 2$ & $320 \mathrm{f}$ & $1730 \mathrm{e}$ & $2680 \mathrm{de} f$ & $2700 \mathrm{def}$ \\
\hline & Mean & $305 \mathrm{e}$ & $1665 \mathrm{~d}$ & $2610 \mathrm{~d}$ & $2635 \mathrm{de}$ \\
\hline
\end{tabular}

Control $1=$ fertilizer as recommended dose

Control $2=$ Urea - form + rock $-\mathrm{P}+\mathrm{K}$ - feldspar 
The results in Fig. 1 showed the effect of acidulation, regardless the concentration, on total yield of sesame and wheat crops which had the same direction of seeds, grains and straw of two crops. The results also revealed that salicylic acid, again, was superior to other acids treatment as the order of acid effectiveness is as follows: salicylic $>$ tartaric $>$ fulvic $>$ humic $>$ sulphuric $>$ oxalic acids. This was explained by Srivastava and Dwivedi (2000) who found the application of salicylic acid (SA) enhanced plant tolerance to many abiotic stresses; the SA favors some plants physiological functions which may work as a key role in enhancing plants growth.

Also, Yasser et al. (2011) mentioned that, humic acid is considered a suitable applicatiocn for improving the vegetative growth, yield production and the antioxidant activity of plants. Also, Yusuff et al. (2009) suggested that, humic acid may improve urea nitrogen use efficiency as well as increasing soil exechangeable $\mathrm{NH}_{4}{ }^{+}$and available $\mathrm{NO}_{3}{ }^{-}$while retaining more $\mathrm{N}$ in soil.

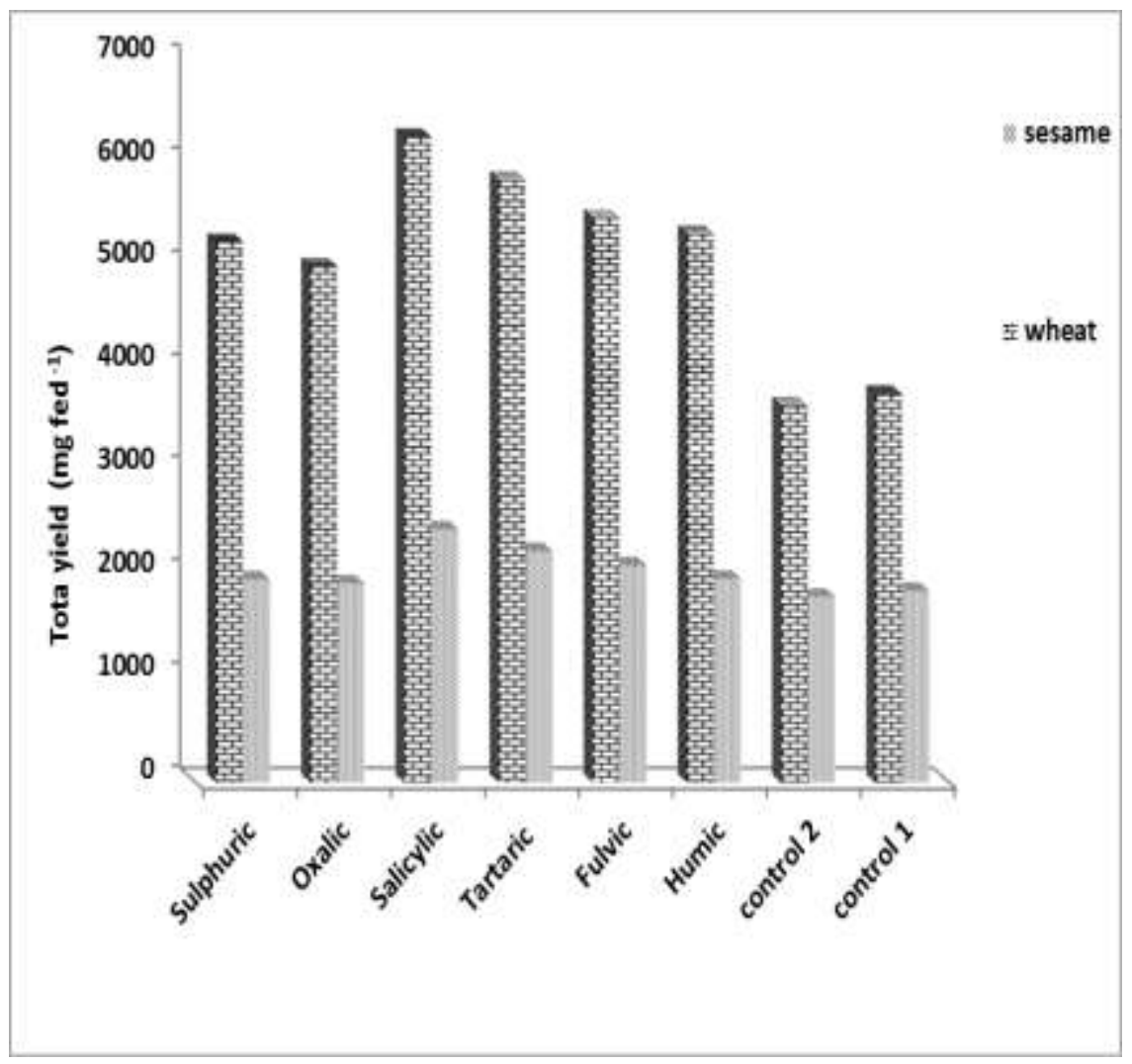

Fig 1. Effect of natural alternative fertilizer acidulation on total yield of wheat and sesame crops

Egypt. J. Soil Sci. 56, No.3 (2016) 


\section{Status of N,P and K in grown plants}

The effect of treatments on total contents of N, $\mathrm{P}$ and $\mathrm{K}$ of seeds and straw for seseame along with the grains and straw for wheat crops are shown in Fig 2. Results indicated that values of total N,P and K total content increased significantly with application of urea form, rockphosphate and feldspar (alternative fertilizer) under the effect of acidulation compared to control treatments. of course, this may be due to the acidulation which improved the translocation of elements from roots to all parts of plant. Nardi et al. (1996) mentioned that the stimulation of root gorwth is generally more apparent than stimulation of shoot growth under conditions of organic acids application. Again, the response to salciyic acid was superuior than other acids; C2 (15\%) were most effective.

\section{Sesame crop}
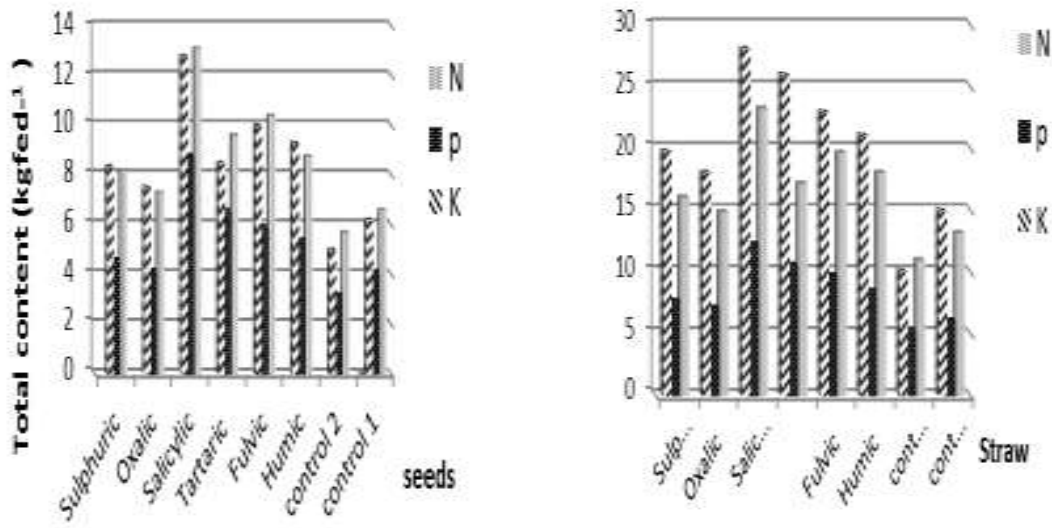

\section{Wheat crop}
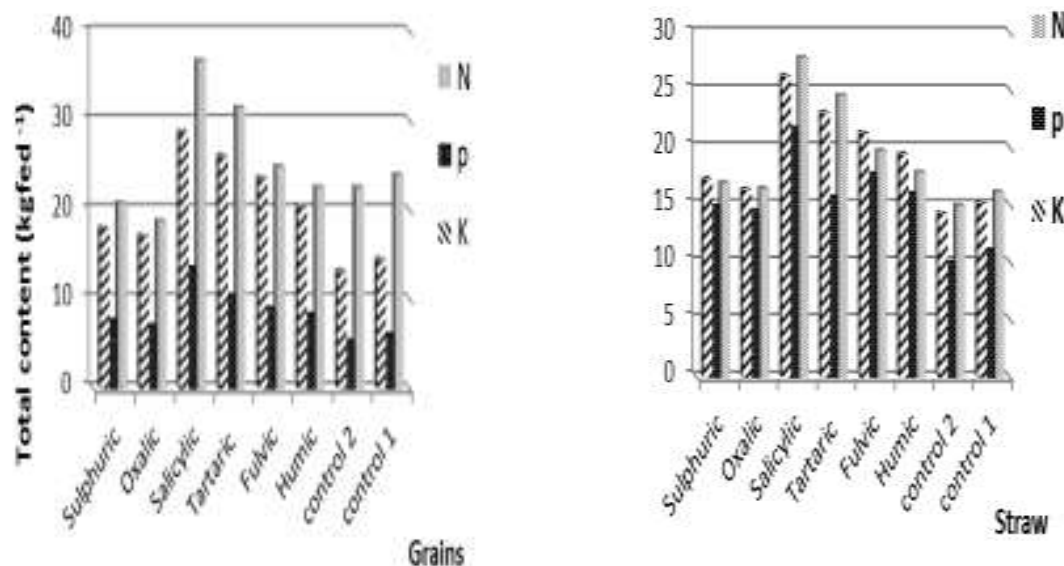

Fig 2. Effect of natural alternative fertilizer acidulation on total content of seseme and wheat crops 
Finally, the addation of urea form , rock - phosphate and feldspar (alternative fertilizer) mixed by other acids ethier organic or inorganic acids to sandy soil may improve the status and release of nutreients espcially $\mathrm{P}$ and $\mathrm{K}$. Rengel and Domon (2008) found that the best performance of feldspar plus compost or organic acids could be attributed to differential exudation of organic compounds, which facilitate the release of non- exchangeable potassium (NEK) and considered to be a mechanism for differential $\mathrm{K}$ uptake efficiency. Also, according to the theory of phosphate solubilization mechanism (PSM), availability may be a resultant of the process of solubilization due to the production of organic acids which is accompanied by the acidification of the medium (Puente et al., 2004).

\section{Conclusion}

From the above-mentioned results, it could be concluded that the application of NPK from acidulated urea- form, rock phosphate or K- feldspar (alternative fertilizer) treated with acidulation especially the high rate of applied acids (15), may improve the soil chemical properties such as $\mathrm{pH}$ along with status of availability of NPK in sandy soil within release from these fertilizer. Also, results revealed that the effect of salicylic acid was more efficient than other organic acids. This has reflected on growth behavior of wheat and sesame crops including either total content of nutrients or total biological yields. Therefore, this work was a simulation in the availability of nutrients affected with exudate roots.

\section{References}

Ali, H. J., Israa, A., Hameed, M. and Badry, A. N. (2015) Effect of some treatments on alleviating of environmental stress on growth and yield of squash (Cucurbittc pepo L.) . Mesop. Environ. J. 4, 67-74.

Canellas, L.P., Olivares, F.L., Okorokova-Facanha, A.L. and Facanha, A.R. (2002) Humic acids isolated from earthworm compost enhance root elongation, lateral root emergence and plasma membrane H-ATPase activity in maize roots. Plant Physiology, 130, 1951-1957.

Chen, Y., Clapp, C.E. and Magen, H. (2004a) Mechanisms of plant growth stimulation by humic substances: The role of organic-iron complexes. Soil Sci. and Plant Nutri. 50, 1089-1095.

Chen, Y., Nobili, M. and Aviad, T. (2004b) Stimulatory effect of humic substances on plant growth. In: Magdoft F., Ray R. (Ed.): Soil Organic Matter in Sustainable Agriculture. CRC Press, Washington.

Chen, J.P., Hans B. and Lothar, B. (2000) Wethering of rocks induced by lichen colonization. Catena, 39, 121-146.

Egypt. J. Soil Sci. 56, No.3 (2016) 
INFLUENCE OF ORGANIC ACIDS ON NUTRIENTS AVAILABILITY... 515

Cottenie, A., Verloo, M., Kiek, L., Velghe, G. and Camerlynek, R. (1982) “Chemical Analysis of Plants and Soils" Lab. Anal. and Agroch. State Univ., Ghent, Belgium

Gümü , S. and Seker, C. (2015) Influence of humic acid applications on modulus of rupture, aggregate stability, electrical conductivity, carbon and nitrogen content of a crusting problem soil. Solid Earth, 6, 1231-1236

Hartman, A. (1988) Ecophysiological aspects of growth and nitrogen fixation in Azospirillium species. Plant Soil, 110, 225-238.

Hassan, H.S.A., Saleh, M.M.S. and Abd El-Kader, A.A. (2010) Growth and leaf mineral content of some fruit species seedlings as affected by a slow release nitrogen fertilizer. Res. J. Agric. Biol. Sci., 6, 417-423.

He, Z. L., Yao, H., Calvert, D.V., Stofella, P.J., Yang, X.E., Chen, G. and Lloyed, G.M. (2005) Dissolution characteristic of central Florida phosphate rock in an acidic sandy soil. Plant Soil, 273, 157 - 166.

Liu, P.P., Bai, J.H., Ding, Q.Y., Shao, H.B., Gao, H.F. and Xiao, R. (2012) Effects of water level and salinity on TN and TP contents in marsh soils of the Yellow River Delta, China. Clean - Soil, Air, Water, 40, 1118-1124.

Lv, Y.-C, Xu, G., Sun, J.N., Brestič1, M., Živčák, M. and Shao, H.B. (2015) Phosphorus release from the soils in the Yellow River Delta: dynamic factors and implications for eco-restoration. Plant Soil Environ. 8, 339-343.

Marschner, H. (1995) "Mineral Nutrition of Higher Plants". 2 ed. Academic Press, London.

Nardi, S., Condheri, G. and Dell'Agnola, G. (1996) Biological Activity of Humus. In: A. Piccolo (Ed.), Humic Substances in Terrestrial Ecosystems, pp. 361-406.

Netik, A., Torres, N.V., Riol, J.M. and Kubicek, C.P. (1997) Uptake and export of citric acid by Aspergillus niger is reciprocally regulated by manganese ions. Biochim. Biophy. Acta, 1326, 287-294.

Page, A.L., Miller, R.H. and Keeney, D.R. (1982) "Methods of Soil Analysis" Amer. Soc. Agron., Madison, Wisconsin, U.S.A.

Puente, M. E., Bashan, Y., Li, C.Y. and Lebsky, V. K. (2004) Microbial populations and activities in the rhizoplane of rock weathering desert plants root colonization and weathering of igneous rocks. Plant Biol. 6, 629-642.

Rengel, Z. and Damon, P. M. (2008) Crops and genotypes differ in efficiency of potassium uptake and use. Physiol. Plant. 133, 624-636.

Russo, R.O. and Berlyn, G.P. (1990) The use of organic biostimulants to help low input sustainable agri. Jour. of Sustainable Agriculture, 1, 19-42.

Seddik, Wafaa M.A. (2011) Evaluation of vinasse,organic manure and natural minerals as alternative natural fertilizers. J. Bio.Chem. Environ.Sci. 6,269-292.

Egypt. J. Soil Sci. 56, No.3 (2016) 
Seddik, Wafaa M.A. and Osman, Mona A. (2015) Impact of feldspar acidulation on potassium dissolution and pea production. Intern. J. of Chem. Res. 8 , 1-10.

Seddik, Wafaa M. A., Youssef, Gehan H. and El -Etr, Wafaa T. (2011) Efficiency of some slow release and fast release fertilizers and organic manures on soil nutrients availability and nutritional status of carrot. Egypt. J. of Appl. Sci. 26 (12B) 576-591.

Singh, M., Singh, V.P. and Reddy, D.D. (2002) Potassium balance and release kinetics under continuous rice-wheat cropping system in vertisol. Field Crop Res., 77, 81-91.

Snedecor, G.W. and Cochran, (1982) "Statistical Methods" $7^{\text {th }}$ edition. Iowa State Univ. Press., Ames., IA., U.S W.G.A.

Song, S.K. and Huang, P.M. (1988) Dynamics of potassium release from potassium bearing minerals as influenced by oxalic and citric acids. Soil Sci. Soc. Am. J. 52 383-390.

Srivastava, M.K. and Dwivedi, U.N. (2000) Delayed ripening of banana fruit by salicylic acid. Plant Sci. 158, 87-96.

Tan, K.H. (2003)" Humic Matter in Soil and the Environment". Marcel Dekker, NewYork

Ugolini, F.C. and Sletten, R.S. (1991) The role of proton donors in ped-ogenesis as revealed by soil solution studies. Soil Sci. 151, 59-75.

Wang, F.L. and Alva, A.K. (1996) Leaching of nitrogen from slow- release urea sources in sandy soils. Soil Sci. Soc. Amer. J., 60, 1454-1458.

Wang, J.B., Chen, Z.H., Chen, L.J., Zhu A.N. and Wu, Z.J. (2011) Surface soil phosphorus and phosphatase activities affected by tillage and crop residue input amounts. Plant, Soil and Environ. 57, 251-257.

Welch, S.A., Taunton, A.E. and Banfield, J.F. (2002) Effect of microorganisms and microbial metabolites on apatite dissolution. Geomicrobiol. J. 19, 343-367

Yasser, M. Ahmed, Shalaby, E.A. and Shanan, Nermeen, T. (2011) The use of organic and inorganic cultures in improving vegetative growth, yield characters and antioxidant activity of Roselle plants (Hibiscus sabdariffa L.) Afr. J. of Biotechnology, 11, 1988-1996.

Yusuff, M., Ahmed, O. and Majid, N. (2009) Effect of mixing urea with humic acid and acid sulphate soil on ammonia loss, exchangeable ammonium and available nitrate. Amer. J. Enviro. Sci. 5, 588-591.

(Received: $26 / 4 / 2016$ accepted: 4/8/2016) 
INFLUENCE OF ORGANIC ACIDS ON NUTRIENTS AVAILABILITY... 517

\section{تأثثير الاحماض العضوية على تيسر العناصر الغذائية من الأسمدة

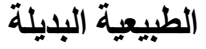

وفاء محم احمد صديق ، وجيدة زكريا حسن و هناء عطية زين العابدين

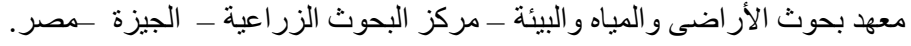

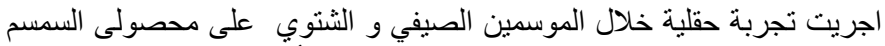

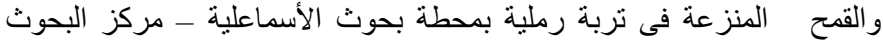

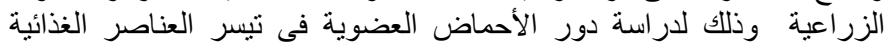

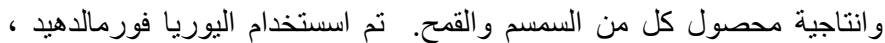

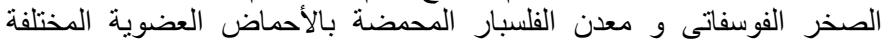

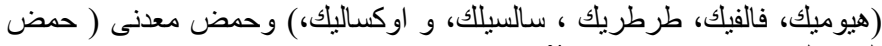

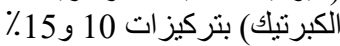

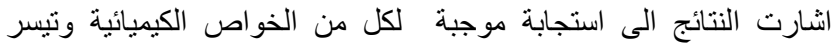

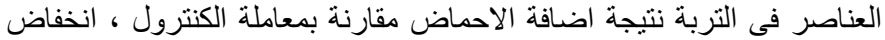

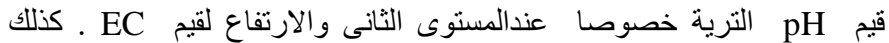

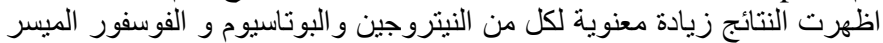

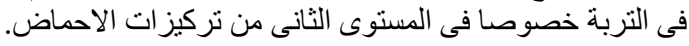

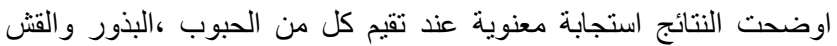

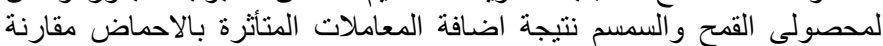

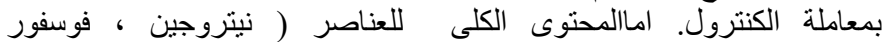

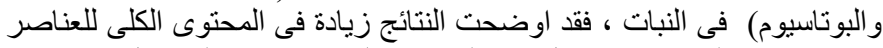

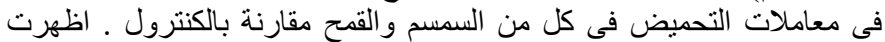

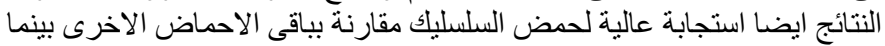

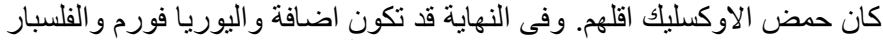

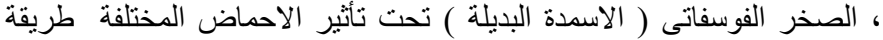

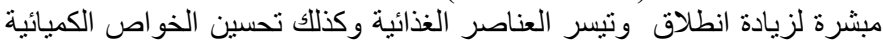

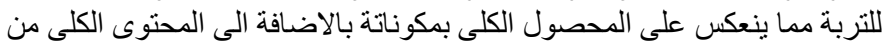
العناصر الغذائية. 